\title{
With Luxembourg in Mind ... The Remaking of National Policies in the Face of ECJ Jurisprudence
}

\author{
Michael Blauberger \\ Paper presented at the EUSA Twelfth Biennial International Conference \\ Boston, MA, March 3-5, 2011
}

\begin{abstract}
This contribution analyses EU member state political responses to ECJ challenges. Faced with high consensus requirements at the European level, member states often have to respond unilaterally and explore how to pursue autonomous regulatory goals in 'ECJ-proof' ways. Based on an actor-centered institutionalist framework, member states' domestic responses to one prominent series of ECJ judgments (Laval, Rüffert, Commission vs Luxembourg) are traced empirically. By anticipating potential legal challenges through the European Commission or private parties and building on existing legal precedent, the case studies show that member state governments manage to preserve significant parts of their original legislation while making it ECJ-proof.
\end{abstract}

Michael Blauberger, Jean Monnet Fellow

European University Institute / RSCAS

Via delle Palazzine 17

I- 50014 San Domenico di Fiesole

Email: michael.blauberger@eui.eu 


\section{INTRODUCTION $^{1}$}

When the European Court of Justice (ECJ) delivered its preliminary ruling on the Laval ${ }^{2}$ case in December 2007, critical comments on the EU's judiciary reached an extraordinary level. The ECJ was accused of promoting "social dumping" and launching an "attack on workers' rights" (cf. Mayer 2009: 8). Due to the ECJ's expansive interpretation of European market freedoms, it was argued, the "very autonomy of Member States' labour and social constitutions is undermined" (Joerges and Rödl 2009: 13). As a response, commentators considered the "nuclear option" of member states' deliberate non-compliance with European jurisprudence in order to constrain court activism (Scharpf 2009b: 200). Notably, recent criticism towards the ECJ is not limited to accusations of "social blindness" from the left. Referring to a different strand of jurisprudence (on anti-discrimination), the conservative and former German president Roman Herzog pleaded to "Stop the European Court of Justice" which was accused of "depriving member states of their very own fundamental competences" (Herzog and Gerken 2008).

Certainly, balancing community and autonomy has become ever more delicate for the ECJ in an enlarged and deeply integrated European Union (EU). Yet, the nuclear option of outright resistance against ECJ rulings has not been drawn or threatened by member state governments. At the same time, joint responses to correct the European judiciary are faced with high consensus requirements of EU decision-making. Consequently, challenged by ECJ jurisprudence, member state governments are typically left with one immediate option to respond: They may explore unilaterally how to preserve domestic regulatory goals in a way that is compatible with the requirements of the European judiciary. Thus, in response to the ECJ's preliminary ruling in the Laval case, the Swedish government mandated a commission to inquire possible legislative action (Swedish Government 2008: 8): 
"The objective must be to maintain the fundamental principle in the Swedish labour market: that the main responsibility for regulating pay and employment terms and conditions has been assigned to the social partners. At the same time, Community law (...) must also be fully respected”

This contribution investigates when and how member state governments re-regulate "with Luxembourg in mind", i.e. trying to partly preserve their domestic regulatory autonomy while solving and anticipating conflicts with EU law. The next section locates the study within the literature on judicialisation. Section three develops an actor-centred institutionalist approach to study the underlying interests and the strategies of member state governments for making domestic regulation ECJ-proof. On this basis, section four analyses EU member states' legislative responses to a series of three closely interrelated ECJ judgments: Laval, Rüffert ${ }^{3}$, and Commission vs Luxembourg ${ }^{4}$. In contrast to the harsh initial reactions, the text concludes that EU member states have been able to preserve their original regulatory goals in ECJ-proof ways, albeit to varying degrees and through different strategies.

\section{POLITICAL RESPONSES TO EUROPEAN JURISPRUDENCE}

EU judicial politics has attracted increasing attention by scholars of European integration during the past decade. The debate moved beyond the intergovernmentalism vs. neofunctionalism divide and specified mechanisms and scope conditions of European integration through law. The close linkage of national and European courts through preliminary reference procedures, the differing time horizons of judges and politicians, the self-sustaining nature of legal discourse and precedent, and the role of private litigation were put forward to account for the strength of the European judiciary (Stone Sweet 2010). As a result, the ECJ decides not only individual cases of conflict, but influences more broadly the strategic behaviour of political actors. 
Most studies on this "judicialisation of politics" focus at the EU level (see Stone Sweet 2010: 27-28). For example, the European Commission has been shown to instrumentalise the threat of court activism to overcome member state resistance against European legislation (Schmidt 2000). In principle, member states may respond collectively to European jurisprudence by further harmonising EU policies or by turning back court-driven integration through re-nationalisation policies. In both directions, however, member states face high consensus hurdles. Whereas the latter option of overriding the ECJ has proven to be largely hypothetical (Stone Sweet and Brunell 2010), positive integration often lacks behind and can only partially compensate for court-driven negative integration (Scharpf 2009a: 6f.).

At least in the short run, therefore, EU member states can only respond to ECJ challenges at the national level (see Figure 1). Domestic responses to European jurisprudence are often difficult to detect and have attracted relatively little attention in the Europeanisation literature (Töller 2010: 429). A strand of this research which also addresses the role of the ECJ centres on questions of compliance (Panke 2007). Most prominently, Lisa Conant has argued that EU member states typically “contain” compliance by applying ECJ rulings only to individual court cases while neglecting their broader policy implications (Conant 2002: 32). Yet, the "contained compliance" approach only partly captures domestic responses to European jurisprudence. Member state governments may come under pressure to adjust their policies more broadly in order to avoid the legal uncertainty of further Court challenges (Schmidt et al. 2008). Various recent policy studies have found the ECJ to trigger significant changes at the national level, even in areas which were no genuine EU policy exists, e.g. regarding corporate taxation (Genschel and Jachtenfuchs 2010) and healthcare policy (Martinsen and Vrangbæk 2008). What is more, these adjustments can only insufficiently be described in terms of compliance or non-compliance. ECJ rulings hardly ever prescribe a specific policy response, but rather circumscribe a legal corridor within which member states have different options to remake their policies. 


\begin{tabular}{|l|l|l|l|}
\hline & F less integration & \multicolumn{2}{|c|}{ more integration $\rightarrow$} \\
\hline $\begin{array}{l}\text { EU } \\
\text { Level }\end{array}$ & \multicolumn{2}{|c|}{ harmonisation } \\
\hline $\begin{array}{l}\text { National } \\
\text { Level }\end{array}$ & non-compliance & $\begin{array}{r}\text { ECJ-proof } \\
\text { domestic regulation }\end{array}$ & regulatory surrender \\
\hline
\end{tabular}

Figure 1: Political responses to European jurisprudence

Thus, even full compliance normally comprises a variety of possible national responses to ECJ jurisprudence and the criterion of compliance captures only one, though important, aspect of them. Instead of looking top-down and asking for the ECJ's power to induce member state compliance, we may take a bottom-up perspective and analyse member state governments' strategies to pursue autonomous regulatory goals in ECJ-proof ways. This approach focuses on the grey area between outright non-compliance and 'regulatory surrender' (i.e. a situation in which compliance with EU law fully determines or even preempts domestic action). The following section proposes an analytical framework to assess empirically if and through which strategies member state governments still manage to defend regulatory autonomy in ECJ-proof ways.

\section{REGULATING WITH LUXEMBOURG IN MIND}

Why and how do EU member state governments (re-)regulate "with Luxembourg in mind"? Two aspects need to be addressed separately in order to answer these questions: actors' interests and the strategic setting within which they are pursued (cf. Frieden 1999: 39). The next subsection discusses when member states governments actually have an interest in regulating with Luxembourg in mind. Subsequently, the institutional setting is examined and two types of strategies to arrive at ECJ-proof domestic regulation are distinguished. 


\section{Balancing community and autonomy}

When should we expect member states to respond to ECJ jurisprudence in a way that accommodates autonomous regulatory goals to the requirements of European law? The first part of this question has been answered by the Europeanisation literature. In order to expect any domestic response to an EU impulse, there need to be, first, some latent "misfit" (or ‘mismatch' Héritier 1996) between existing European and national and, secondly, interested actors who actually transform this misfit into adaptational pressures (Börzel and Risse 2007: 490-491). In addition, it is argued here, if their constituency has a strong interest in preserving the regulatory status quo, national policy-makers need to balance community compatibility and regulatory autonomy.

When the ECJ finds national rules incompatible with European law, it creates pressure to adjust at the domestic level; member states have to respond somehow. Nevertheless, one must not overestimate the ECJ's power to promote domestic change single-handedly. In her study on the German Bundestag, Tracy Slagter (2009) has shown how national legislators may respond in a rather limited and punctual way as long as they are only challenged by individual ECJ judgements. Such a national strategy of "wait and see" (Slagter 2009: 190), however, gets more difficult to sustain if the ECJ builds up broader lines of legal reasoning in series of cases and successively fills the legal gaps of previous judgements. If challenging ECJ jurisprudence goes along with continuous case supply by the Commission and/or private litigants, national policy-makers face strong adaptational pressures; "contained compliance" or even outright non-compliance are hardly an option.

Sometimes, ECJ rulings provide welcome opportunities for incumbent member state governments to get rid off unwanted rules from its predecessors while shifting the blame to the EU level (Tallberg 2002: 27). When they are confronted with simultaneous pressure to preserve national regulation after an ECJ challenge, however, member state governments face a dilemma. If their own constituency is negatively affected by an ECJ ruling, regulatory 
surrender is not an option either. Under this condition, the question of how to preserve the remaining national regulatory autonomy in a community-compatible way becomes crucial. Thus, when analysing domestic responses to ECJ jurisprudence, we have to take the interests of the governments' constituency into account rather than assuming a genuine interest in protecting national regulatory autonomy.

In sum, neither some legal misfit nor its challenge through an ECJ ruling will normally trigger an automatic response at the national level. Interests matter, both in order to turn a particular misfit into adaptational pressures and to counter these pressures in order to preserve autonomous national regulation. As a result, EU member state governments cannot easily escape a situation of conflicting pressures to preserve and to adjust domestic regulation. They have to re-regulate with Luxembourg in mind.

\section{Strategies of ECJ-proof regulation}

In order to make national legislation ECJ-proof, member state governments need to be creative. A great diversity of possible strategies to arrive at community-compatible regulation exists: For example, member states may emulate regulations of other countries that have already been found to be community-compatible by the Court; they may go for an informal approval of draft legislation by the European Commission, they may support national regulation by the collection of extensive factual evidence; or they may promote private selfregulation instead of formal legislation in order to avoid legal conflicts at the EU level .

But how can the diversity be organised into meaningful categories or types of national regulatory strategies? And what accounts for a governments' choice of one type of strategy rather than another? The main proposition here is to distinguish member states' regulatory strategies according to whose possible challenges they try to anticipate (see Figure 2). The main actors who supply the Court with cases are the European Commission and, mostly via national courts, private litigants. The choice of national regulatory strategy, I hypothesize, 
depends on the anticipated legal procedure, i.e. the channel through which judicial challenges of national regulation would most likely reach the ECJ.

Under Article 258 TFEU, the Commission initiates infringement proceedings against member states and, when necessary, submits cases to the ECJ. If national policy-makers are threatened by an infringement proceeding, they will attempt to anticipate potential challenges of the Commission, e.g. through informal contacts to Brussels. In fact, most infringement proceedings get closed at an early stage. An alternative or complementary route to the Court is a preliminary reference according to Article 267 TFEU. Whereas direct access to the European courts is limited for private parties, national courts may provide indirect access for private litigants by requesting preliminary rulings from the ECJ. Thus, if national policymakers are uncertain about the potential result of a preliminary reference from a domestic court, they will try to avoid private litigation in the first place, e.g. by including social partners in the process of regulation or by mitigating conflicts about rule application before they reach the courts.

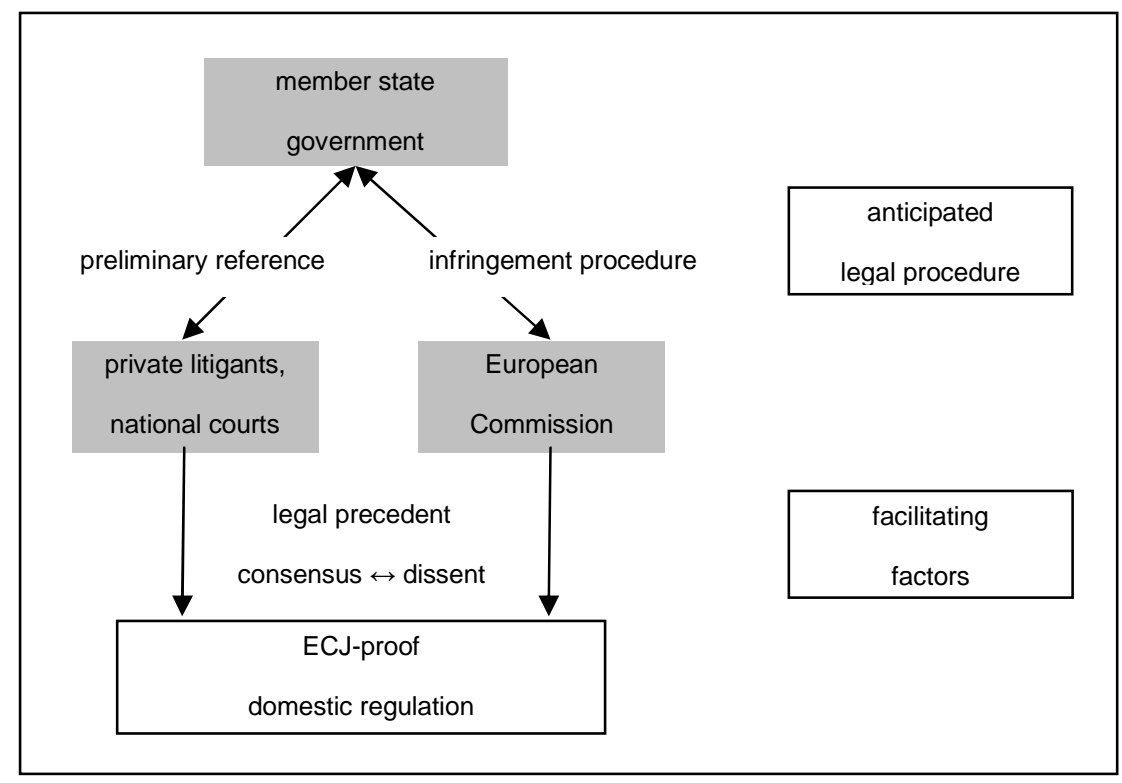

Figure 2: A strategic framework: national legislation in the face of ECJ jurisprudence

In addition, one may ask for favourable scope conditions or facilitating factors which increase member states' chances of success to arrive at autonomous and community-compatible rules. 
Two hypotheses will be analysed in the case studies. First, legal precedent reduces the costs of designing community-compatible rules and the uncertainty about possible legal challenges. If the ECJ has already explicitly endorsed national regulation in one case, other member states can use this template for designing their own policies ECJ-proof and for discouraging potential litigators. Less formal, if the Commission negotiates a compromise with one member state government and refrains from initiating or further pursuing an infringement proceeding, this compromise may become a model for other countries as well.

Second, depending on the strategic context, political consensus or dissent reduces the risk of legal challenges against domestic regulation. On the one hand, preliminary references by national courts are less likely, if the regulatory status quo is supported by a strong societal consensus. For example, Marlene Wind (2010) explains the reluctance of Swedish and Danish courts to refer cases to the ECJ by consensual and corporatist features of national policymaking: "The Nordic states are unitary states, extremely homogeneous and have a corporatist structure. Conflicts are therefore usually resolved outside the court system" (Wind 2010: 1059). On the other hand, infringement proceedings are less likely, if the Commission itself is split regarding the community-compatibility of national measures. Decisions are taken by the Commission as a collective body (i.e. de jure by an absolute majority and de facto mostly consensual) and compliance research hints at the Commission's selectiveness in pursuing possible infringements (Conant 2002: 75f.). As a consequence, internal dissent in the Commission may raise member states' opportunities to find support at the EU level and to avoid infringement action.

\section{NATIONAL RESPONSES TO THE POSTED WORKERS CASES}

Based on the analytical framework outline before, the remainder of this text analyses national responses to a series of closely interrelated ECJ judgements: Laval, Rüffert and Commission vs Luxembourg. The cases have been chosen for three main reasons. To begin with, given the 
extraordinary public attention they attracted, these judgements are "most likely cases" to find member state governments under simultaneous pressures to adjust and to preserve national rules. At the same time, many observers interpreted the judgments as severe restrictions of national regulatory autonomy. They are, therefore, "hard cases" concerning member states' chances successfully to preserve national autonomy in an ECJ-proof way. Finally, the cases offer sufficient variation with regard to the factors discussed before, including judicial action via national courts and the Commission. Before analysing national legislative responses, the cases will be briefly presented.

\section{Laval, Rüffert, Commission vs Luxembourg}

The ECJ ruled on Laval, Rüffert and Commission vs Luxembourg in late 2007 and early 2008 and it soon became common to refer to these cases as a distinct series of judgments. In addition, the judgment in Viking 5 is usually regarded to complete the ECJ's "Laval quartet" (Malmberg 2010: 8). The rulings challenged national measures to protect workers' rights in the context of EU enlargement. In Laval, Rüffert and Commission vs Luxemburg, national measures were found to restrict the European freedom of services under the Posted Workers Directive 96/71/EC (in the following: PWD). According to the PWD, the Court ruled, member states were not allowed to apply their entire terms and conditions of work to posted workers, but only a nucleus of mandatory rules for minimum protection.

The Laval conflict involved the Swedish building workers' union (Byggnads) and a Latvian construction company (Laval un Partneri) which had been commissioned to build a school in Vaxholm, Sweden. After negotiations on the working conditions of posted workers had failed between these two parties, Laval signed a collective agreement with a Latvian trade union instead. Swedish trade unionists denied the validity of this agreement and took collective action by blocking the construction site. Laval brought the conflict to the Swedish Labour Court which eventually referred the case to the ECJ. In brief, the ECJ acknowledged 
the fundamental right of trade unions to take collective action, but found the concrete actions disproportionate. In addition, the Swedish "Lex Britannia" which permitted collective action irrespective of existing collective agreements under foreign law was found to be discriminatory.

The Rüffert judgement challenged the Public Procurement Act of the German Land Lower-Saxony. According to this act, construction firms could only win a public tender if they committed themselves by a declaration to pay at least the wages prescribed by the local collective agreement (Tariftreueerklärung, in the following translated as "collective agreements declaration", cf. Rödl 2009: 2). A German company won a tender and subcontracted work to a Polish company. When it became public that Polish workers were paid less than their German colleagues at the site, the government annulled the contract and imposed financial penalties. The German company's complaint reached the ECJ as a preliminary reference. The Court ruled that Lower Saxony's Public Procurement Act imposed an unjustified restriction of the freedom to provide services under the PWD, in particular as it protected only workers in the public sector and referred to collective agreements that were not universally applicable.

Finally, Commission vs Luxembourg resulted from an infringement proceeding of the European Commission which argued that Luxembourg's legislation went beyond what was allowed under the PWD and, thus, constituted an unjustified restriction of the freedom of services. Referring to Article 3(10) of the PWD on public policy exceptions, Luxembourg had extended its entire regulation regarding terms and conditions of employment to situations of cross-border service provision. The ECJ followed the Commission's argument and declared that Luxembourg, by imposing requirements on foreign service providers that were not covered by a narrow interpretation of the public policy exception, had implemented the Posting of Workers Directive incorrectly. 
The ECJ judgments spurred strong reactions, not just in the member states affected, but also at the European level. In a resolution of 22 October 2008 on "Challenges to Collective Agreements in the EU', the European Parliament suggested a reform of the PWD. The same month, the Commission organised a "Forum on Workers' Rights and Economic Freedoms" to consult member states and social partners on the consequences of the ECJ's rulings. It soon became clear, however, that community legislative action was unlikely to develop in the near future (Bücker and Warneck 2010: 121f.). A joint report of European social partners from March 2010 on the Laval quartet shows fundamental disagreement about the legal (un)certainty provided by the ECJ's rulings and the desirability of a reform of the PWD (European Social Partners 2010: 7, 14). In the run-up to his re-election in September 2009, Commission President Barroso proposed an EU Regulation instead of revising the PWD; an idea that was taken up in Mario Monti's "New Strategy for the Single Market" reported to the Commission in May 2010 and included in the Commission's proposal “Towards a Single Market Act” in November 2010.

In the short and medium term, therefore, EU member states had to react domestically to the Laval jurisprudence. By the end of 2010, legislative responses to the three ECJ judgments were taken in four countries - those directly affected plus Denmark (Eurofound 2010: 24f.). In the following, these legislative responses will be analysed in turn.

\section{Laval: Swedish and Danish responses}

The ECJ's judgement in Laval was perceived as a profound challenge to existing Swedish legislation and to the country's system of autonomous collective bargaining as well as an indirect threat to similar structures in Denmark (Malmberg and Sigeman 2008). Particularly contentious was the Court's interpretation of the PWD as providing a largely exhaustive catalogue of working conditions to be guaranteed for posted workers (Joerges and Rödl 2009: 17). Collective agreements which are not declared universally applicable and which require 
more favourable working conditions than the "nucleus" circumscribed by the Directive were found to "misfit" with EU law.

After the ECJ had identified this legal misfit, the threat of continued private litigation created strong adaptational pressures in Sweden and Denmark. In its response to the judgment, the Confederation of Swedish Enterprise (Svenskt Näringsliv) welcomed the Laval ruling and called for quick legislative change. In Denmark, a similar case had emerged in 2005, but was not referred to the ECJ (Neergaard and Nielsen 2010: 44f.). After Laval, however, the Danish court could have hardly upheld its argument that it was sufficiently clear that collective action does not constitute an unjustified obstacle to European market freedoms.

By contrast, the European Commission did not actively challenge Swedish and Danish legislation and showed internal tensions. When the former Commissioner for Internal Market and Services McCreevy publicly criticised the Swedish government and Swedish unions during the conflict, President Barroso had to clarify that the Commission did not take sides (Lindstrom 2010: 1315). In Court, the Commission did not challenge any of the two parties' claims, leaving it essentially to the ECJ and national courts to balance on a case-by-case basis (ibid.: 1317). ${ }^{6}$ After the judgment, the Commission still argued that it was for national authorities and social partners to come up with adequate responses. This was interpreted as an indication "that the Commission will not, in its capacity as guardian of the Treaty, insist on a strict interpretation of the case law concerning the Posting of Workers Directive, but rather allow the Member States some margin of appreciation when adjusting their different industrial relation regimes to the new case law" (Malmberg 2010: 10).

The initial reactions of the Swedish and Danish governments were the same: Given that joint European action was highly unlikely in the near future, commissions were appointed to propose domestic legislative adjustments in response to the ECJ's jurisprudence (Malmberg 2010: 10-14). As already cited in the introduction, their mandate was to preserve as far as possible, the systems of autonomous collective bargaining in a community-compatible way. 
The national commissions concluded their work at different rates and, largely following the commissions' proposals, legislative changes were adopted by the end of 2008 in Denmark and by the end of 2009 in Sweden.

The Danish ${ }^{7}$ and Swedish ${ }^{8}$ legislative responses exhibit important commonalities: Both reforms were developed in co-operation with social partners and reaffirm the autonomy of collective bargaining, rather than resorting to one of the options to regulate posted work explicitly recognized by the Court, i.e. by setting a statutory minimum wage or by declaring collective agreements generally binding (Rönnmar 2010: 285). Based on an "innovative reinterpretation" (Bücker and Warneck 2010: 22) of Article 3(8) of the PWD, foreign service providers are now informed that they can be required to conclude an agreement which corresponds to existing collective agreements "concluded by the most representative employers' and labour organisations at national level and which are applied throughout national territory" (for a detailed legal discussion, cf. Swedish Government 2008: 22-25). At the same time, in order to comply with the ECJ's jurisprudence, collective bargaining and collective actions became subject to several restrictions. Collective agreements can only be extended to posted work if they define minimum working conditions and do not go beyond the "hard core" of the PWD. Moreover, foreign service providers must obtain sufficient information in advance on the requirements which may be imposed upon them. For this purpose and in order to help solving potential conflicts at an early stage, the role of the Swedish Work Environment Authority as a liaison office was strengthened.

A closer look at the legislative responses to Laval, however, reveals significant differences. Overall, the Danish response explores more boldly the limits of the remaining national regulatory autonomy. Danish legislation defines "minimum pay" more widely than the Swedish reform (Kilpatrick 2009: 858; Malmberg 2010: 12-13). Conditions regarding holidays and leave that are imposed upon Danish employers may be "converted" into a fixed sum when calculating the minimum pay demanded from foreign service providers. In 
addition, the Swedish reform explicitly prohibits collective action if the employer can show that the posted workers enjoy at least as favourable conditions as follow from the minimum conditions of a collective agreement. This "evidential requirement" can be met by the employer through a collective agreement in the home country or simply through personal employment contracts (Rönnmar 2010: 285). Finally, the Swedish Lex Britannia was amended in order to preclude collective action if the conditions of the Posting of Workers' Act are fulfilled (ibid.).

Two factors explain these differences: First, regarding governments' interests, the Swedish liberal-conservative government was only half-heartedly committed to preserve national regulation which it mainly perceived to benefit the constituency of Social Democrats. Swedish Prime Minister Reinfeldt had been openly critical of Byggnads in the Laval conflict before he came into office in 2006 (see also Davesne 2009; Woolfson et al. 2010: 341). The Swedish legislative reform following Laval was criticised by the opposition in parliament and by unions for restricting collective action rights even beyond what was required by the ECJ and for lowering the protection of workers even when posted from outside the European Economic Area (Rönnmar 2010: 285).

Second, as to the strategic setting, a lack of societal consensus made it more difficult for the Swedish government than for the Danish to balance autonomous regulation with the requirements of European law. Swedish trade unions took an uncompromising position from the beginning of the Laval conflict (Davesne 2009: 12). At the same time, the Swedish Employers' Confederation saw the legal challenges as an opportunity to question collective action rights and provided financial support to the Latvian company before the Swedish Labour Court (Woolfson et al. 2010: 341). The Swedish Laval commission consulted the social partners, but its proposals did not satisfy any of the two camps (ibid.: 344). By contrast, the Danish response was motivated by a broad societal consensus to pro-actively preserve the existing model of autonomous collective bargaining, and not by a direct challenge of the ECJ. 
Social partners were equal members in the Danish tripartite Laval commission. Its final report was short, delivered already in June 2008 and reflected a consensus among social partners and politicians (Bücker and Warneck 2010: 23). The report of the Swedish government's commission comprises more than 400 pages, it engages in a detailed analysis of potential legal conflicts, and the legislative changes proposed just entered into force in April 2010 (Malmberg 2010: 14):

"The (Danish) idea seems to be to reach a national compromise which will not be challenged (...) In Sweden it was clear early on that no such consensus would be reached (...) If the Danish report seems anxious not to uncover any hidden obstacles for the compromise, the intention of the Swedish report seems to be to leave no stone unturned in finding a solution that could not be legally questioned.”

In sum, Sweden and Denmark managed to limit the constraining impact of EU law and to remake domestic legislation in ECJ-proof ways. The Court's narrow interpretation of the PWD clearly challenged national regulatory autonomy, but both countries upheld their systems of autonomous collective bargaining. In order to make their new legislation ECJ-proof, both governments centrally addressed the concerns of potential private litigants, while infringement action by the Commission was not perceived as imminent. Different levels of societal consensus account for the varying degrees to which the original domestic regulation was preserved. Whereas the Swedish response was heavily contested by societal actors and resulted in a cautious and legalistic reform, broad societal consensus was a precondition in Denmark for finding a quick and so far uncontested legislative answer to the ECJ's challenge.

\section{Rüffert: Varying responses of German Länder}

The Rüffert case marked the climax of a political and legal battle about the protection of labour standards in public procurement which had been fought for years in Germany (Rödl 
2009: 3-6). Due to the failure to agree on a federal law on collective agreement declarations, various Länder introduced corresponding provisions into their public procurement law; governments led by Social Democrats (SPD) as well as by Conservatives (CDU/CSU). As a result of this previous history, both major parties were under significant pressure to preserve autonomous regulation after Rüffert. At the same time, Länder governments could not simply ignore the judgment: The ruling strongly re-affirmed the ECJ's reasoning in Laval; there were explicit threats of private litigation in the case of non-compliance which could have even involved damages claims; besides private litigation, the Commission also took a pronounced position which was largely congruent with the Court's final ruling and, hence, legislative inaction would most likely lead to infringement procedures.

As an immediate response to Rüffert, all German Länder with similar legislation as Lower-Saxony disapplied the contested provisions in April and May 2008. Yet, the judgment has not led to a complete abolishment of collective agreement declarations (see Table 1). Instead, several Länder revised their legislation in order to defend at least partly the original idea of the declarations while making it ECJ-proof. The variance of political responses is already interesting from a purely methodological point: Rüffert did not challenge German federal, but regional law which allows us to compare legislative responses across different German Länder.

\begin{tabular}{|l|l|l|l|l|}
\hline Land & gov. parties & collective agreement declarations & min. wage & date of revision \\
\hline \multicolumn{7}{|c|}{ conservative/liberal governments } \\
\hline $\begin{array}{l}\text { Baden- } \\
\text { Württemberg }\end{array}$ & CDU, FDP & No & - & - \\
\hline Bavaria & CSU, FDP & No (abolished after Rüffert) & - & $04 / 2008$ \\
\hline Hesse & CDU, FDP & No (disapplied after Rüffert) & - & $04 / 2008$ \\
\hline Lower-Saxony & CDU, FDP & Yes & - & $12 / 2008$ \\
\hline Saxony & CDU, FDP & No & - & - \\
\hline $\begin{array}{l}\text { Schleswig- } \\
\text { Holstein }\end{array}$ & CDU, FDP & No (disapplied after Rüffert) & - & $05 / 2008$ \\
\hline \multicolumn{1}{|c|}{ mixed governments } & - & $04 / 2010$ \\
\hline Hamburg & CDU, Green & Yes & - & $\sim 2011$ \\
\hline $\begin{array}{l}\text { Mecklenburg- } \\
\text { West Pom. }\end{array}$ & CDU, SPD & Yes (planned) & - & $09 / 2010$ \\
\hline \begin{tabular}{l} 
Saarland \\
\hline
\end{tabular} & CDU, FDP, & Yes & Green
\end{tabular}




\begin{tabular}{|l|l|l|l|l|}
\hline Saxony-Anhalt & CDU, SPD & No & - & - \\
\hline Thuringia & SPD, CDU & Yes (planned) & - & $09 / 2010$ (draft) \\
\hline \multicolumn{5}{|l|}{ social democrat/green governments } \\
\hline Berlin & SPD, Left & Yes & $€ 7,50$ & $06 / 2010$ \\
\hline Brandenburg & SPD, Left & Yes (planned) & $€ 7,50$ & $08 / 2010$ (draft) \\
\hline Bremen & SPD, Green & Yes & $€ 7,50$ & $11 / 2009$ \\
\hline $\begin{array}{l}\text { North-Rhine } \\
\text { Westphalia }\end{array}$ & SPD, Green & Yes (planned) & $?$ & $\sim 2011$ \\
\hline $\begin{array}{l}\text { Rhineland- } \\
\text { Palatinate }\end{array}$ & SPD & Yes & $€ 8,50$ & $11 / 2010$ \\
\hline
\end{tabular}

Table 1: Collective agreement declarations after Rüffert

By and large, the overall pattern of legislative reform can be explained by looking at the governing parties and the interests of their main constituencies (cf. Sack 2010). Länder governed by centre-right coalitions (CDU/CSU, FDP) largely abolished the contested provisions - if they had any rules on collective agreement declarations in the first place. The presence of the liberal party (FDP) in government fits almost perfectly with the absence of provisions on collective agreement declarations. The picture is diverse as regards governing coalitions which cannot be clearly classified as centre-right or centre-left. This mixed picture reflects the internal divide of the CDU/CSU on the issue of collective agreement declarations (Rödl 2009: 6). Labour and unions may not be the core constituency of the conservative party, but their interests can hardly be ignored by conservatives either. Finally, all governments led by the social-democrats (SPD) reformed or are still reforming their public procurement legislation so as to include social criteria in public tenders, comprising the requirement of collective agreement declarations.

The variance of political responses to Rüffert is telling for yet another reason. One can observe a trend from legally rather modest to more bold attempts of Länder governments to explore the limits of their regulatory autonomy. Lower-Saxony which was first to revise its public procurement legislation and which, at first sight, seems an exception among centreright governments, kept a very restricted and largely symbolic reference to collective agreement declarations. These are demanded only in the construction sector in which, by now, a generally binding collective agreement exists anyway. Bremen was the first Land to 
introduce a specific minimum wage for public procurement into its revised law which, however, does not apply to companies from other EU member states. Eventually, the comeback of encompassing collective agreement declarations, including minimum wages for public procurement, was further promoted through the precedent set by Länder such as Berlin and Rhineland-Palatinate.

The centre-left government of Berlin commissioned three legal surveys in order to explore its ECJ-proof options to tie public tenders to social criteria. On this basis, a farreaching new procurement law was adopted in June 2010, including the requirement of collective agreement declarations, a minimum wage of $€ 7.50$ and other social and ecological criteria for public tenders. Since then, Berlin provides a significant example in two respects: First, it gives other Länder governments (e.g. in Brandenburg) legal guidance about how to revise public procurement legislation in a community-compatible way. Second, reference to Berlin is made by non-governmental forces, mainly left opposition parties and unions, in order to demand similar reforms and to refute blame-shifting to the European level.

In sum, Rüffert has provided some Länder governments an opportunity to abolish or disapply the requirement of collective agreement declarations, but it has not ruled out entirely the possibility to include social provisions in public procurement legislation. Facing the threat of both, further private litigation and infringement action of the Commission, Länder governments proceeded carefully: firstly, they suspended existing provisions and, then, they gradually explored new ways to legally include social considerations into public procurement legislation.

\section{Commission vs Luxembourg: A strategy of "trial and error"}

At first sight, Luxembourg's legislative response to the ECJ's ruling in Commission vs Luxembourg comes close to "regulatory surrender" as defined earlier. The Commission's main contention concerned Luxembourg's implementation of the PWD which declared that 
all laws, regulations and administrative provisions on working conditions constituted mandatory provisions falling under national public policy and, therefore, applied entirely to workers posted to Luxembourg. Article 1(1) of the implementing law provided an extensive list of fourteen issues that were considered essential for the regulation of working conditions. Four of these points were questioned by the Commission and found to constitute unjustified restrictions of European services freedom by the ECJ: the monitoring of written employment contracts, the automatic indexation of salaries, the rules on part-time and fixed-term work, and the regulation of collective labour agreements. The revised law basically declares the contested provisions inapplicable to posted workers; the "unique goal" of the legislative revision being explicitly "to bring legislation in conformity with European jurisprudence". 9

The picture looks different, however, if we consider more broadly the motives for the original implementing law of 2002 and the revision process in 2010. In 2002, Luxembourg had deliberately opted for a legislative strategy of "trial and error", i.e. interpreting its autonomy to regulate posted work extensively first and, then, being taught about its limits by the Commission and the ECJ. François Biltgen, Luxembourg's minister of labour and employment responsible for drafting the original and the revised law, justifies the decision not to informally negotiate the original law with the Commission: ${ }^{10}$

"In fact, such negotiations would have just resulted in imposing a priori upon Luxembourg a 'neoliberal' interpretation of the Posted Workers Directive (...) Instead, the government - with the consent of social partners and parliamentpreferred to design the law according to its own vision of social Europe and national social public policy. (This approach) implicated a certain risk of legal action by the Commission, although the Directorate General for Employment and Social Affairs, for its part, was not a priori opposed (...) The government was aware that a condemnation by the ECJ was possible." 
Thus, the original law was written on the basis of a very broad interpretation of national regulatory autonomy, supported by societal consensus at home and speculating on internal dissent of the Commission. Legislation was adopted under considerable legal uncertainty, no legal precedent on the correct interpretation of the PWD existing, and some evidence suggests that other member states like Ireland, Italy and Belgium adopted a similar strategy (Eurofound 2010: 19).

The ECJ's judgment in Commission vs Luxembourg set a precedent that narrowed the interpretation of permissible public policy exceptions from the services freedom. Faced with this precedent, Luxembourg's government adhered to the goal of preserving "l'esprit du législateur de 2002”, but clearly refrained from further exploring uncertain legal territory. The proposition of labour representatives to subsume per se all collective agreements with general applicability under the public policy exception encountered the resistance of employers' representatives and was not followed up. The idea of limiting the definition of posted work temporally and with reference to tasks that are "not part of the normal activity" of a company was dropped after a formal objection of the State Council which warned about new infringement action. ${ }^{11}$

In sum, although the ECJ undoubtedly constrained Luxembourg's regulatory autonomy, it did so in a rather limited way. ${ }^{12}$ Luxembourg's legislative response to the ECJ's judgement was a step back from an initially very extensive interpretation of the PWD, deliberately taking the risk of a legal challenge by the Commission rather than “overimplementing" (Conant 2002: 70) the Directive from the beginning.

\section{CONCLUSION}

This contribution tackled a question which is challenging for both, political decision-makers responding to the ECJ and students of European judicial politics: How to take the law seriously (Joerges 1996) and, at the same time, not take it too seriously? In the examples 
given, EU member states could hardly ignore or limit to the specific case the implications of the ECJ's judgments for their national policies. To avoid further conflicts and the legal uncertainty involved, member state governments had to take the Court's challenges seriously and remake their policies in community-compatible ways. Yet, they still had room for manoeuvre and creativity, to pursue at least parts of their original regulatory interests. In analytic terms, existing ECJ jurisprudence and the threat of litigation provided the strategic setting which conditioned, but did not determine member states' political action. Furthermore, the chances to successfully accommodate national policies with EU law depended on both, political factors (consensus or dissent among potential litigants) as well as legal factors (existence or absence of legal precedent).

The present focus on domestic political responses to the European judiciary has been justified with EU member states' difficulties to react jointly. In fact, controversial ECJ judgments are often preceded by disagreement between and within member states in the first place. This makes joint decisions to politically revert or complement ECJ-driven integration very unlikely, at least in the short- and medium-term. Unless balancing community and autonomy in the EU is left entirely to the dialogue of courts, therefore, member state governments often need to explore domestically their remaining autonomy. Ultimately, studying domestic responses to the ECJ also helps to better understand decisions taken at the EU level: First, the Court may become "sensitised" to domestic concerns through member states' political responses and, accordingly, "fine-tune" its own jurisprudence (Obermaier 2008: 26). Secondly, member state governments may shape political integration by uploading their own regulatory responses to ECJ-driven integration to the European level. Domestic regulation "with Luxembourg in mind" then serves as a model of autonomy-regarding integration at the EU level. 


\section{NOTES}

${ }^{1}$ I would like to thank Alexandre Afonso, Philipp Genschel, Marie-Pierre Granger, Miriam Hartlapp, Adrienne Héritier, Dan Kelemen, Juan A. Mayoral, Diana Panke, Susanne K. Schmidt, Anne Thies, Benjamin Werner and Rebecca Zahn for their very helpful comments. I am grateful to the Robert Schuman Center for Advanced Studies in Florence, where this text was written during my time as a Jean Monnet fellow. Research is based on the project "Political autonomy in the European multilevel legal system", funded by the German Science Foundation's Collaborative Research Centre 597 “Transformations of the State” at the University of Bremen.

${ }^{2}$ Case C-341/05, Laval un Partneri Ltd, ECR 2007, I-11767.

${ }^{3}$ Case C-346/06, Rüffert, ECR 2008, I-1989

${ }^{4}$ Case C-319/06, Commission v Luxembourg, ECR 2008, I-4323

${ }^{5}$ Case C-438/05, Viking, ECR 2007, I-10779. In contrast to the other cases, Viking was decided on the basis of the freedom of establishment which makes the case rather specific. The following analysis, therefore, compares domestic responses to the three other rulings.

${ }^{6}$ The impression that the Commission shied away from taking a more pronounced position because the conflict was "politically much too sensitive" was confirmed by an interview with a member of the Commission's Legal Service, 30 November 2010.

${ }^{7}$ Act on amendment of the Act on Posting of Workers, adopted 18.12.2008, entry into force 01.01.2009.

${ }^{8}$ Changes to the Co-Determination Act and the Posting of Workers' Act, adopted 05.11.2009, entry into force 15.04.2010.

${ }^{9}$ Loi du 11 avril 2010 portant modification des articles L. 010-1, L. 141-1, L. 142-2, L. 142-3 et L. 142-4 du Code du Travail. The law and the legislative process are documented in Dossier parlementaire No. 5942, online: http://www.chd.lu/wps/portal/public/RoleEtendu?action=doDocpaDetails\&id=5942 (Last checked: 10 February 2011). For the citation, translated by the author, see p. 12 in document 5942/00 "Exposé des motifs".

${ }^{10}$ See Endnote 8, p. 5 in document 5942/00 “Exposé des motifs", translated by the author.

${ }^{11}$ See Endnote 8, p. 4-5 in document 5942/05 “Avis du Conseil d'Etat”.

${ }^{12}$ Luxembourg's parliamentary committee of labour and employment concludes: "It needs to be emphasised that the judgement and the present reform are far from substantially endangering Luxembourg's social legislation. 
The reform introduces some necessary adjustments which preserve social legislation at the same time as clarifying its applicability to posted workers", see Endnote 8, p. 7 in document 5942/08 "Rapport de la Commission du Travail et de l'Emploi”, translated by the author.

\section{REFERENCES}

Börzel, T. A. and Risse, T. (2007) 'Europeanization: The Domestic Impact of European Union Politics', in K. E. Jørgensen, M. A. Pollack and B. Rosamond (eds.), Europeanization: The Domestic Impact of European Union Politics. London: Sage Publications, pp. 483-504.

Bücker, A. and Warneck, W. (eds.) (2010) Viking - Laval - Rüffert: Consequences and Policy Perspectives, Brussels, European Trade Union Institute (ETUI).

Conant, L. (2002) Justice Contained: Law and Politics in the European Union, London/Ithaca: Cornell University Press.

Davesne, A. (2009) The Laval Case and the Future of Labour Relations in Sweden, Paris: Sciences Po, Les Cahiers Européens No 01/2009.

Eurofound (2010) Posted Workers in the European Union, Dublin: European Foundation for the Improvement of Living and Working Conditions.

European Social Partners (2010) Report on Joint Work of the European Social Partners on the ECJ rulings in the Viking, Laval, Rüffert and Luxembourg Cases.

Frieden, J. A. (1999) 'Actors and Preferences in International Relations', in D. A. Lake and R. Powell (eds.), Actors and Preferences in International Relations. Princeton: Princeton University Press, pp. 39-76.

Genschel, P. and Jachtenfuchs, M. (2010) 'How the European Union Constrains the State: Multilevel Governance of Taxation', European Journal of Political Research: forthcoming.

Héritier, A. (1996) 'The Accomodation of Diversity in European Policy-Making and its Outcomes: Regulatory Policy as a Patchwork', Journal of European Public Policy 3(2): 149-176.

Herzog, R. and Gerken, L. (2008) Comment: Stop the European Court of Justice, Freiburg: Centre for European Policy.

Joerges, C. (1996) 'Taking the Law Seriously: On Political Science and the Role of Law in the Process of European Integration', European Law Journal 2(2): 105-135.

Joerges, C. and Rödl, F. (2009) 'Informal Politics, Formalised Law and the 'Social Deficit' of European Integration: Reflections after the Judgments of the ECJ in Viking and Laval', European Law Journal 15(1): 1-19.

Kilpatrick, C. (2009) 'Laval's Regulatory Conundrum: Collective Standard-setting and the Court's New Approach to Posted Workers', European Law Journal 34(6): 844-865.

Lindstrom, N. (2010) 'Service Liberalization in the Enlarged EU: A Race to the Bottom or the Emergence of Transnational Political Conflict?' Journal of Common Market Studies 48(5): 1307-1327.

Malmberg, J. (2010) Posting Post Laval. International and National Responses, Uppsala: Uppsala Center for Labor Studies. Working Paper 2010:5.

Malmberg, J. and Sigeman, T. (2008) 'Industrial Actions and EU Economic Freedoms: The Autonomous Collective Bargaining Model Curtailed by the European Court of Justice', Common Market Law Review 45(4): 1115-1146. 
Martinsen, D. S. and Vrangbæk, K. (2008) 'The Europeanization of Health Care Governance: Implementing the Market Imperatives of Europe', Public Administration 86(1): 169184.

Mayer, F. C. (2009) 'Der EuGH und das soziale Europa', in Friedrich Ebert Stiftung (ed.) Der EuGH und das soziale Europa. Berlin: Friedrich Ebert Stiftung, pp. 7-25.

Neergaard, U. and Nielsen, R. (2010) Blurring Boundaries: From the Danish Welfare State to the European Social Model?, Copenhagen.

Obermaier, A. J. (2008) Fine-Tuning the Jurisprudence: The ECJ's Judicial Activism and Self-Restraint, Vienna: Working Paper No. 02/2008.

Panke, D. (2007) 'The European Court of Justice as an Agent of Europeanization. Inducing Compliance with EU Law', Journal of European Public Policy 14(6): 847-866.

Rödl, F. (2009) The ECJ's Rüffert-Judgement: A Case for "Undistorted" Wage Competition, Cambridge: Harvard European Law Working Paper No. 01/2009.

Rönnmar, M. (2010) 'Laval Returns to Sweden: The Final Judgment of the Swedish Labour Court and Swedish Legislative Reforms', Industrial Law Journal 39(3): 280-287.

Sack, D. (2010) 'Europäisierungsdruck und Parteiendifferenz in den deutschen Bundesländern. Die Rechtsprechung des EuGH und die Novellierung von Tariftreueregelungen', Politische Vierteljahresschrift 51(4):619-42.

Scharpf, F. W. (2009a) The Double Asymmetry of European Integration. Or: Why the EU Cannot Be a Social Market Economy, Köln: MPIfG Working Paper 09/12.

Scharpf, F. W. (2009b) 'Legitimacy in the Multilevel European Polity', European Political Science Review 1(2): 173-204.

Schmidt, S. K. (2000) 'Only an Agenda Setter? The European Commission's Power over the Council of Ministers', European Union Politics 1(1): 37-61.

Schmidt, S. K., Blauberger, M. and van den Nouland, W. (2008) 'Jenseits von Implementierung und Compliance. Die Europäisierung der Mitgliedstaaten', in I. Tömmel (ed.) Jenseits von Implementierung und Compliance. Die Europäisierung der Mitgliedstaaten. Wiesbaden: VS Verlag für Sozialwissenschaften, pp. 275-296.

Slagter, T. H. (2009) 'National Parliaments and the ECJ: A View from the Bundestag', Journal of Common Market Studies 47(1): 175-197.

Stone Sweet, A. (2010) 'The European Court of Justice and the Judicialization of EU Governance', Living Reviews in European Governance 5(2).

Stone Sweet, A. and Brunell, T. L. (2010) 'Overriding the European Court of Justice? Qualitative Evidence from Cases in the Carruba, Gabel, and Hankla Data Set (19871997)', Yale: Yale Law School, Public Law Working Paper No. 217.

Swedish Government (2008) Action in Response to the Laval Judgment. Summary, Stockholm: Swedish Government Official Reports.

Tallberg, J. (2002) 'Delegation to Supranational Institutions: Why, How, and with What Consequences?' West European Politics 25(1): 23-46.

Töller, A. (2010) 'Measuring and Comparing the Europeanization of National Legislation: A Research Note', Journal of Common Market Studies 48(2): 417-444.

Wind, M. (2010) 'The Nordics, the EU and the Reluctance towards Supranational Judicial Review', Journal of Common Market Studies 48(4): 1039-1063.

Woolfson, C., Thörnqvist, C. and Sommers, J. (2010) 'The Swedish Model and the Future of Labour Standards after Laval', Industrial Relations Journal 41(4): 333-350. 